
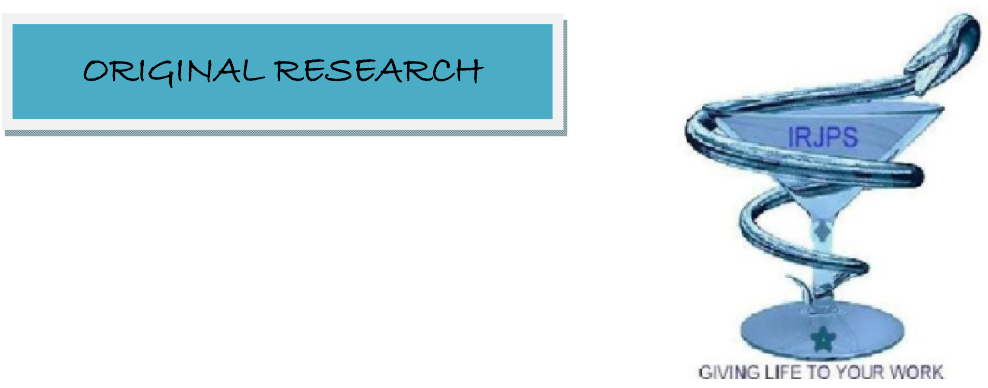

\title{
UV SPECTROPHOTOMETRIC ESTIMATION OF ESOMEPRAZOLE AND DOMPERIDONE IN TABLET DOSAGE FORM
}

\author{
Vitthal S. Hiwale*, Parag T. Bakshe, Sachin S. Rane, Rajesh Y. Chaudhari, Vijay R. Patil \\ Department of Pharmaceutical Chemistry, T.V.E.S.'s Hon. L. M. C. College of Pharmacy, \\ Faizpur- 425 503, Dist-Jalgoan, (M.S.), India.
}

Submitted on27.09.16;

Revised on: 22.10.16;

Accepted on: 05.11.16

\begin{abstract}
:
Here an accurate, precise, sensitive and economical spectrophotometric methodwas developed and validated for simultaneous estimation of Esomeprazole and Domperidone tablet dosage form. The UV method employed was Simultaneous Equation Method. The method employs $304 \mathrm{~nm}$ as $\lambda 1$ and $285 \mathrm{~nm}$ as $\lambda 2$ for formation of equations. Esomeprazole and Domperidone obeys Beer's law in the concentration range 2-32 $\mu \mathrm{g} / \mathrm{ml}\left(\mathrm{r}^{2}=0.9939\right)$ and 5-60 $\mu \mathrm{g} / \mathrm{ml}\left(\mathrm{r}^{2}=0.9977\right)$. The mean recovery for Esomeprazole and Domperidone were found to be 99.12 and $99.43 \%$ respectively. The developed method were validated according to ICH guidelines and values of accuracy, precision and other statistical analysis were found to be in good accordance with the prescribed values. Thus the proposed methods were successfully applied for simultaneous determination of Esomeprazole and Domperidone routine industrial work.
\end{abstract}

KEY WORDS: Esomeprazole, Domperidone, Validation, Simultaneous Equation Method.

Corresponding Author: Vitthal S. Hiwale E-mail : baksheparag89@gmail.com
Indian Research Journal of Pharmacy and Science; 10(2016) 804-810 Journal Home Page: https://www.irjps.in 


\section{INTRODUCTION}

Drugs play a vital role in the progress of human civilization by curing diseases. Analytical chemistry is divided into two branches qualitative and quantitative ${ }^{1}$ Esomeprazole (ESO) is a chemically, (S)-(-)-5-Methoxy-2-[(4-methoxy-3,5-

dimethylpyridin-2-yl)methylsulfinyl]-3Hbenzoimidazole ${ }^{2}$, Domperidone (DOM) is, 5-chloro1-[-1-[3-(2,3-dihydro-2-oxo-1H-benzimadozol-1-

yl)propyl]-4-piperidinyl]-1,3-dihydro-2H-

benzimidazol-2-one ${ }^{3}$. ESO and DOM combination is used in treatment of gastrointestinal disorders. ESO is a proton pump inhibitor which reduces acid secretion through inhibition of ATPase enzyme in gastric

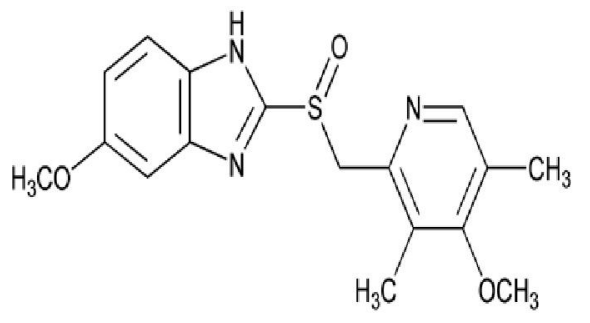

Esomeprazole parietal cells and prevents formation of gastric acid. DOM is an antidopaminergic drug and used to suppress nausea and vomiting. Several methods are available in the literature for the determination of ESO and DOM. Most of these methods are for the determination of ESO and DOM separately or in combination with other drug. Analytical methods reported for quantitative determination of ESO individually in pharmaceutical formulations or biological fluids are $\mathrm{HPLC}^{4,5,6}$ and $\mathrm{UV}^{7,8,9}$. Analytical methods reported for quantitative determination of DOM individually in pharmaceutical formulations or biological fluids are HPLC ${ }^{10,11,12,13}$.

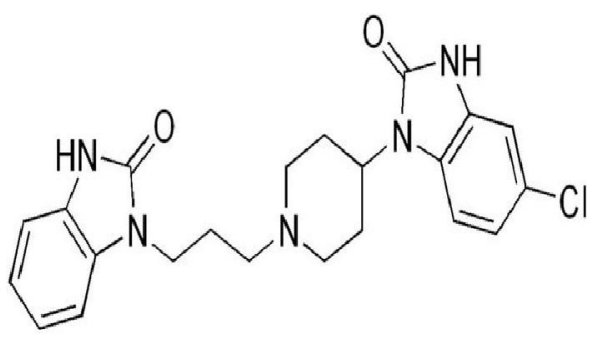

Domperidone

Figure 1 Chemical structure of Esomeprazole and Domperidone

\section{EXPERIMENTAL}

\section{Chemicals and reagents}

Esomeprazole and Domperidone were procured from

Glenmark Pharmaceutical Labs. Pvt. Ltd. Commercial pharmaceutical preparation ESOZ D40, manufactured by Glenmark Pharmaceuticals Pvt. Ltd. containing $40 \mathrm{mg}$ of ESO and $30 \mathrm{mg}$ of DOM was collected from local market. Acetonitrile, methanol and water used were of analytical grade (Qualigens Fine Chemicals, Mumbai, India). A $0.45 \mu \mathrm{m}$ nylon filter (Pall life Sciences, Mumbai, India) was used. All other chemicals and reagents used were analytical grade unless otherwise indicated.

\section{Instrumentation:}

The proposed work was carried out on a Shimadzu UV-visible spectrophotometer (model UV-1800 series), which possesses a double beam double detector configuration with al $\mathrm{cm}$ quartz matched cell. All weighing was done on electronic balance (Sansui-vibra DJ-150S-S). A Fast clean ultrasonicate cleaner (India) was used for degassing the mobile phase.

\section{Selection of Solvents}

On the basis of solubility study methanol was selected as the solvent for dissolving ESO and DOM.

Preparation of Standard Stock Solutions of ESO and DOM

\section{ESO Stock Solution}

An accurately weighed quantity of ESO $(25 \mathrm{mg})$ was taken in $25 \mathrm{ml}$ volumetric flask and dissolved in methanol $(20 \mathrm{ml})$ with the help of ultrasonication for about $10 \mathrm{~min}$. Then the volume was made up to the mark using methanol to get ESO standard stock solution $(1 \mathrm{mg} / \mathrm{ml})$.

\section{ESO Working Standard Solution}

ESO standard stock solution $5 \mathrm{ml}$ was diluted to 25 $\mathrm{ml}$ using $72 \% \mathrm{v} / \mathrm{v}$ methanol to get working standard solution $100 \mu \mathrm{g} / \mathrm{ml}$. 


\section{DOM Stock Solution}

An accurately weighed quantity of DOM $(25 \mathrm{mg})$ was taken in $25 \mathrm{ml}$ volumetric flask and dissolved in methanol $(20 \mathrm{ml})$ with the help of ultrasonication for about $10 \mathrm{~min}$. Then the volume was made up to the mark using methanol to get DOM standard stock solution (1 mg / ml).

\section{DOM Working Standard Solution}

DOM standard stock solution $5 \mathrm{ml}$ was diluted to 50 $\mathrm{ml}$ using $72 \% \mathrm{v} / \mathrm{v}$ methanol to get working standard solution $100 \mu \mathrm{g} / \mathrm{ml}$.

Determination of $\lambda$ Max of Individual Component
An appropriate aliquot portion of ESO $(0.2 \mathrm{ml})$ and DOM $(0.1 \mathrm{ml})$ were transferred to two separate $10 \mathrm{ml}$ volumetric flasks, the volume was made up to the mark using $72 \% \mathrm{v} / \mathrm{v}$ methanol to obtain ESO (20 $\mu \mathrm{g} / \mathrm{ml})$ and DOM $(10 \mu \mathrm{g} / \mathrm{ml})$. Drug solutions were scanned separately between $200 \mathrm{~nm}$ to $400 \mathrm{~nm}$. ESO shows $\lambda$ max at $304 \mathrm{~nm}$ while DOM at $285 \mathrm{~nm}$, respectively (Figure1).

\section{Overlay Spectra of ESO and DOM}

The overlain spectrum of both drugs was recorded (Fig.1) and two wavelengths $304.0 \mathrm{~nm}$ ( $\lambda$ max of ESO) and $285.2 \mathrm{~nm}(\lambda$ max of DOM) were selected for further study.

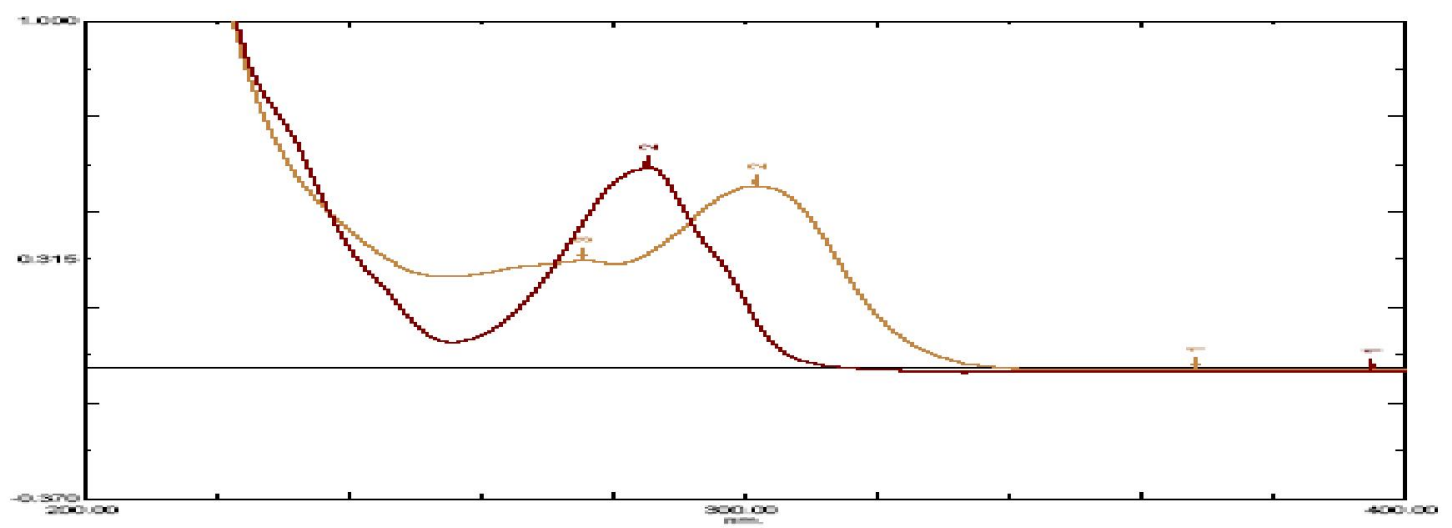

Fig.1: Overlay Spectra of ESO and DOM

\section{Linearity Study for ESO}

An accurately measured aliquot portion of working standard solution of ESO was transferred to seven separate $10 \mathrm{ml}$ volumetric flasks. The volume was made up to the mark using $72 \% \mathrm{v} / \mathrm{v}$ methanol to obtain concentrations $(2-32 \mu \mathrm{g} / \mathrm{ml})$. Absorbance of these solutions was measured at $304 \mathrm{~nm}$, (Table1) Calibration curve was plotted, absorbance Vs concentration as shown in (Fig. 2).

\section{Linearity Study for DOM}

Accurately measured aliquot portions of working standard solution of DOM were transferred to seven separate $10 \mathrm{ml}$ volumetric flasks. The volume was made up to the mark using $72 \% \mathrm{v} / \mathrm{v}$ methanol to obtain concentrations $(5-60 \mu \mathrm{g} / \mathrm{ml})$. Absorbance of these solutions was measured at $285 \mathrm{~nm}$, (Table 1). Calibration curve was plotted, absorbance Vs concentration as shown in (Fig. 3).

Table 1: Regression and Optical characteristics of ESO and DOM

\begin{tabular}{|l|l|l|}
\hline Parameters & Value For ESO & Value For DOM \\
\hline $\begin{array}{l}\text { Beer's law limit } \\
(\boldsymbol{\mu g} / \mathbf{m l})\end{array}$ & $2-32$ & $5-60$ \\
\hline $\begin{array}{l}\text { Correlation } \\
\text { Coefficient (r) }\end{array}$ & 0.9939 & 0.9977 \\
\hline Regression equation & \\
\hline Slope & 0.0142 & 0.0128 \\
\hline Intercept & 0.01749 & 0.0883 \\
\hline
\end{tabular}




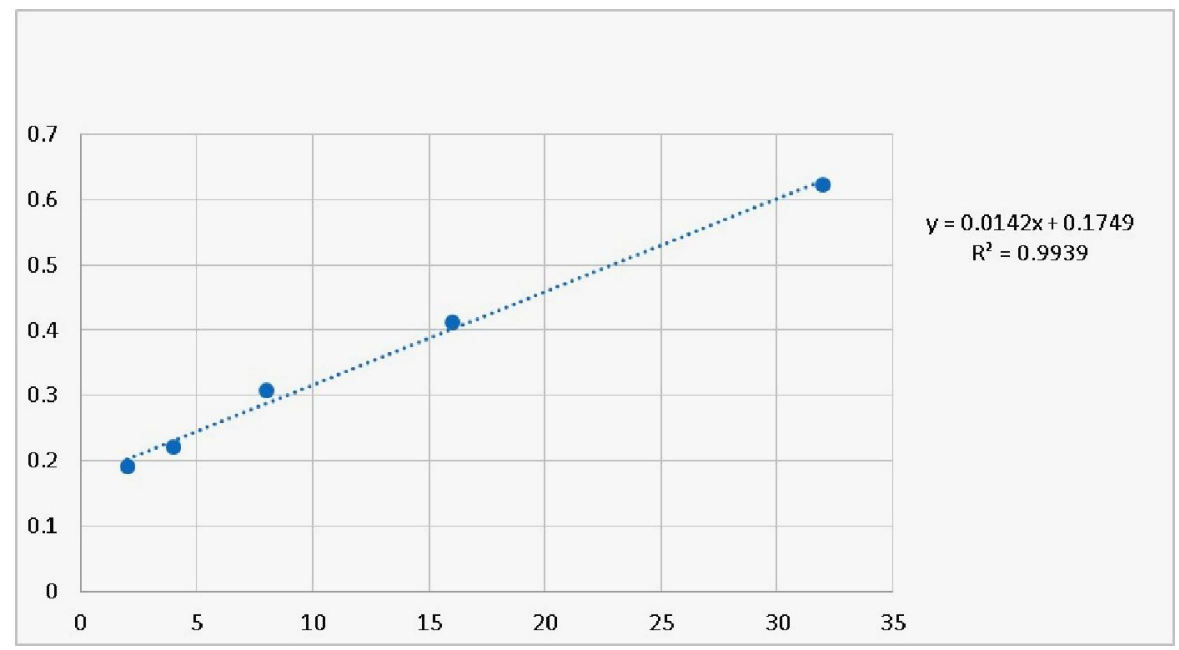

Fig. 2: Calibration Curve of ESO at $304 \mathrm{~nm}$ Wavelength

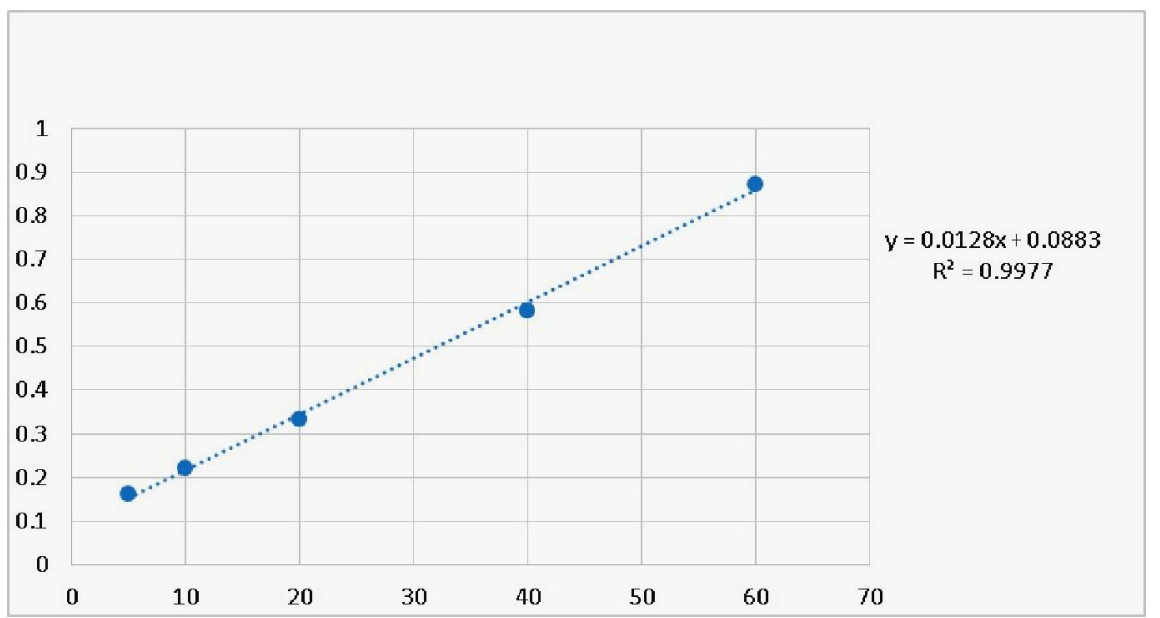

Fig. 3: Calibration Curve of DOM at $285 \mathrm{~nm}$ Wavelength

\section{Estimation of Laboratory Mixture by Proposed Method}

In order to see the feasibility of proposed method for simultaneous estimation of ESO and DOM in marketed pharmaceutical formulations, the method was first tried for estimation of drugs in standard laboratory mixture. Accurately weighed ESO $(50 \mathrm{mg})$ and DOM $(50 \mathrm{mg})$ were taken in $100 \mathrm{ml}$ volumetric flask, dissolved in methanol $(60 \mathrm{ml})$ with the help of ultrasonication for about $10 \mathrm{~min}$ and the volume was made up to mark using the same. Appropriate aliquot portion $(1 \mathrm{ml})$ was transferred to $10 \mathrm{ml}$ volumetric flask and further diluted using $72 \% \mathrm{v} / \mathrm{v}$ methanol to get ESO $(50 \mu \mathrm{g} / \mathrm{ml})$ and DOM $(50 \mu \mathrm{g} / \mathrm{ml})$. The absorbance was recorded at $304 \mathrm{~nm}$ and $285 \mathrm{~nm}$ against solvent as blank.

Amount of each drug was estimated using following equations,

$$
\begin{aligned}
& C_{x}=\frac{A_{2} \times a y_{1}-A_{1} \times a y_{2}}{a x_{2} a y_{1-}-a x_{1} a y_{2}} \\
& C y=\frac{A_{1} \times a x_{2}-A 2 \times a x_{1}}{}
\end{aligned}
$$$$
\operatorname{ax}_{2} \operatorname{ay}_{1-}-\mathrm{ax}_{1} \mathrm{ay}_{2}
$$

Where;

A1 and A2 are the absorbance of diluted mixture at $\lambda_{1}$ and $\lambda_{2}$ 
$\mathrm{Cx}$ and $\mathrm{Cy}$ are the concentration of $\mathrm{X}$ and $\mathrm{Y}$ respectively

ax1 and ax2 are absorptivities of $\mathrm{X}$ at $\lambda_{1}$ and $\lambda_{2}$ respectively ay1 and ay2 are absorptivities of $\mathrm{Y}$ at $\lambda_{1}$ and $\lambda_{2}$ respectively

The results are reported in (Table 2).

Table 2: Results of Estimation of ESO and DOM Standard Laboratory Mixture.

\begin{tabular}{|l|l|l|}
\hline Analyte & $\begin{array}{l}\text { \%Concentration estimated } \\
\text { (Mean } \pm \text { S.D.) }\end{array}$ & \%R.S.D. \\
\hline ESO & $99.43 \pm 0.1415$ & 0.1412 \\
\hline DOM & $99.04 \pm 0.4761$ & 0.4768 \\
\hline
\end{tabular}

*Average of five determinations; R.S.D. = Relative Standard Deviation

Application of the Proposed Method for Estimation of Drugs in Tablets

Twenty 'ESOZ D40' Tablets containing ESO (40 $\mathrm{mg}$ ) and DOM (30 mg) were weighed and ground to fine powder. A quantity of sample equivalent to ESO (40 mg) and DOM (30 mg) was transferred into 100 $\mathrm{ml}$ volumetric flask containing methanol $(60 \mathrm{ml})$, sonicated for $15 \mathrm{~min}$ and the volume was made up to the mark and filtered through Whatman filter paper (No. 45). This solution was $(1 \mathrm{ml})$ transferred to 10 $\mathrm{ml}$ volumetric flaks, dissolved and volume was adjusted to the mark. The absorbance of the solutions was measured at $304 \mathrm{~nm}$ and $285 \mathrm{~nm}$ against blank. The concentrations of two drugs in sample were determined by using simultaneous equations. The results are reported in the (Table 3).

Table 3: Results of Estimation of ESO and DOM in Tablets.

\begin{tabular}{|l|l|l|l|}
\hline Analyte & $\begin{array}{l}\text { Label claim } \\
(\mathbf{m g} / \text { tab) }\end{array}$ & $\begin{array}{l}\text { \% Label claim estimated } \\
\text { (Mean } \pm \text { S.D. })\end{array}$ & \%R.S.D. \\
\hline ESO & 40 & $99.94 \pm 0.57212$ & 0.57360 \\
\hline DOM & 30 & $99.62 \pm 0.64191$ & 0.64992 \\
\hline
\end{tabular}

*Average of five determinations; S.D. =Standard Deviation

\section{Validation of Proposed Method}

The Proposed method was validated as per the $\mathrm{ICH}$ guidelines. $^{14}$

\section{Accuracy [Recovery Study]}

Accuracy of proposed method was ascertained on the basis of recovery study performed by standard addition method. A known amount of standard drug solutions were added to the tablet powder to make final concentrations in the range of $80 \%, 100 \%$ and $120 \%$ and re-analyzed it by the proposed method.
The absorbance recorded and the \% recoveries were calculated using formula.

$\%$ Recovery $=[\mathrm{A}-\mathrm{B} / \mathrm{C}] \mathrm{X} 100$

Where,

$\mathrm{A}=$ Total amount of drug estimated

$\mathrm{B}=$ Amount of drug found on preanalysed

basis

$$
\mathrm{C}=\text { Amount of Pure drug added }
$$

The results are reported in (Table 4).

Table 4: Recovery Study.

\begin{tabular}{|l|l|l|l|}
\hline $\begin{array}{l}\text { Drug in mixture solution } \\
(\boldsymbol{\mu} \mathbf{g} / \mathbf{m l})\end{array}$ & $\%$ Recovery \pm S.D. \\
\hline ESO & DOM & ESO & DOM \\
\hline 30.02 & 20.01 & $99.10 \pm 0.173$ & $99.72 \pm 0.143$ \\
\hline 40.10 & 30.00 & $99.61 \pm 0.369$ & $99.36 \pm 0.463$ \\
\hline 50.05 & 39.98 & $99.32 \pm 0.525$ & $99.12 \pm 0.656$ \\
\hline \multicolumn{4}{|c}{ S.D. $=$ Standard Deviation }
\end{tabular}




\section{Precision}

Precision was determined as intra-day and inter-day variations. Intra-day precision was determined by analyzing $\operatorname{ESO}(39,40$, and $41 \mu \mathrm{g} / \mathrm{ml})$ and $\operatorname{DOM}(29$, 30 , and $31 \mu \mathrm{g} / \mathrm{ml}$ ) for three times on the same day.
Inter-day precision was determined by analyzing the same concentration of solutions for three different days over a period of week. The results are reported in (Table 5).

Table 5: Precision Study.

\begin{tabular}{|l|l|l|l|l|}
\hline Precision & ESO & \%R.S.D. & DOM & \%R.S.D. \\
\hline Interday, $\mathbf{n = 3}$ & $99.25 \pm 0.8231$ & \pm 0.8298 & $99.97 \pm 0.3264$ & \pm 0.3256 \\
\hline Intraday, $\mathbf{n}=\mathbf{3}$ & $99.01 \pm 0.4552$ & \pm 0.4591 & $99.20 \pm 0.3251$ & \pm 0.3271 \\
\hline
\end{tabular}

$\mathrm{RSD}=$ Relative standard deviation

\section{Ruggedness}

Ruggedness of the proposed method was determined by analysis of aliquots from homogenous slot by two different analyst using same operational and environmental conditions. The results are reported in (Table 6).

Table 6: Ruggedness Study.

\begin{tabular}{|l|l|l|l|l|}
\hline & \multicolumn{2}{|l|}{ ESO40 $\boldsymbol{\mu g} / \mathbf{m l}$} & \multicolumn{2}{l|}{ DOM 30 $\boldsymbol{\mu g} / \mathbf{m l}$} \\
\cline { 2 - 6 } & $\begin{array}{l}\text { Amount Found in } \\
\boldsymbol{\mu g} / \mathbf{m l} \text { Mean } \pm \text { S.D. }(\mathbf{n} \\
\mathbf{= 3}\end{array}$ & \% R.S.D. & $\begin{array}{l}\text { Amount Found in } \\
\boldsymbol{\mu g} / \mathbf{m l ~ M e a n ~} \pm \text { S.D.(n }= \\
\mathbf{3}\end{array}$ & \% R.S.D. \\
\hline Analyst-I & $40.17 \pm 0.75498$ & 0.7587 & $30.41 \pm 0.45645$ & 0.45104 \\
\hline Analyst-II & $40.98 \pm 0.47892$ & 0.4732 & $30.57 \pm 0.81658$ & 0.81296 \\
\hline Day-I & $40.91 \pm 0.82329$ & 0.8245 & $30.32 \pm 0.19530$ & 0.19659 \\
\hline Day-II & $39.96 \pm 0.09470$ & 0.2369 & $29.88 \pm 0.08911$ & 0.7140 \\
\hline
\end{tabular}

LOD: Limit of detection of ESO and DOM were found to be $0.06526 \mu \mathrm{g}$ and $0.07313 \mu \mathrm{g}$ respectively. LOQ: Limit of Quantitation of ESO and DOM were found to be $0.08233 \mu \mathrm{g}$ and $0.09769 \mu \mathrm{g}$ respectively.

\section{RESULTS AND DISCUSSION}

A simultaneous UV Spectrophotometric Estimation method was developed for ESO and DOM. The method employs $304 \mathrm{~nm}$ as $\lambda 1$ and $285 \mathrm{~nm}$ as $\lambda 2$ for formation of equations. ESO and DOM obeys Beer's law in the concentration range 2-32 $\mu \mathrm{g} / \mathrm{ml}$ $\left(\mathrm{r}^{2}=0.9939\right)$ and $5-60 \mu \mathrm{g} / \mathrm{ml}\left(\mathrm{r}^{2}=0.9977\right)$. The mean recovery for ESO and DOM was found to be 99.12 and $99.43 \%$ respectively. The developed method were validated according to ICH guidelines and values of accuracy, precision and other statistical analysis were found to be in good accordance with the prescribed values.

\section{CONCLUSION:}

The proposed simultaneous UV Spectrophotometric Estimation method presented in this paper has advantages of simplicity, accuracy, precision and convenience for quantitation of ESO and DOM. The proposed method can be used for the quality control of ESO and DOM in typical laboratories. 


\section{REFERENCES}

1. Jeffery GH. Bassett J. Mandham J. and. Denny RC. editors. Vogel's Text Book of Quantitative Chemical Analysis, Longman Scientific and Technical Pub U.K. 1994; 5th ed: pp.3-4.

2. Sweetman SC. Blake PS. Pearson AV. and McGlashan JM. editors. Martindale: The Complete Drug Reference. 2005; 13th ed: pp. 1225.

3. Hardman JG.and Limbird LE. editors. Goodman and Gilman's The Pharmacological Basics of Therapeutics. New York: McGraw -Hill medical pub. 2001;10th Ed: pp. 1023-1024.

4. Maheshwari DG and Trivedi PD. Simultaneous Estimation of Esomeprazole and Domperidonein Combined Dosage form by HPLC. International Journal of Applied Science and Engineering. 2011: 187-194.

5. Sankar DG. A New Validated Stability Indicating Quantitative RP-HPLC Method for Simultaneous Estimation Of Esomeprazole and Levosulpride in Bulk Drug and Combined Capsule Dosage form. International Journal of Pharmaceutical and Chemical Sciences.2010: 2250-1029.

6. GuptaV, Mishrab D, Rajc K. A Review: Development and Validation of HPLC Method For The Determination of Esomeprazole in Pharmaceuticals, Indo. Global Journal Of Pharmaceutical Sciences. 2(2);2012:191-196.

7. Kratz JM, Teixeira M, Koester LS and Simoes CM. An HPLC-UV Method for The Measurement Of Permeability Of Marker Drugs In The Caco-2 Cell Assay.Brazilian Journal of Pharmaceutical Sciences.Volume 44(6); June 2011: 531-537.

8. Jain MS, Agrawal YS, Chavhan RB, Bari MM and Barhate SD. UV Spectrophotometric
Methods For Simultaneous Estimation Of

Levosulpiride And Esomeprazole In Capsule

Dosage Form. Asian Jouranal of

Pharmaceutical Analysis. Vol. 2: Issue 4; 2012: 106-109.

9. Putta R, Shyale S, Gouda M and Shanta Kumar S. Physicochemical characterization, UV spectrophotometric method development and validatin studies of Esomeprazole Magnesium Trihydrate. International Journal of Pharmaceutical Science.2(3);2010: 484-90.

10. Kranthi kumar V and Sundaraganapathy R. Development and Validation of Rp-Hplc Method for Simultaneous Estimation of Domperidone and Lafutidine In Pharmaceutical Tablet Dosage form. International Journal of Pharmacy and Pharmaceutical Sciences.Vol 5, Issue 2; 2012: 68-72.

11. Chitlange SS, Mulla AI, Pawbake GR and Wankhede SB. A Validated RP-HPLC Method for Simultaneous Estimation of Dexrabeprazole and Domperidone in Pharmaceutical Dosage Form.Pelagia Research Library Der Pharmacia Sinica. 1 (1); 2010:42-47.

12. Sharma S, Sharma AK, Singh O, Chaturvedi AK, Verma V, Arya RK and Singh UK. RPHPLC Method Devlopment and Validation of Domperidone in Solid Dosage Form.Eurasian Journal of Analytical Chemistry.Vol. 1 No. 4; 2012: 330-332.

13. Jain N, Jain R, Jain DK and Jain SK. RP-HPLC Method for Simultaneous Estimation of Esomeprazole Magnesium and Domperidone in A Tablet Dosage form. Bulletin of Pharmaceutical Research.2(3); 2012: 134-139.

14. ICH, Draft Guideline on Validation of Analytical Procedures, Definition and Terminology, Federal Register, 1995, 60 FR 11260. 